OPEN ACCESS

Approved by:

Frontiers Editorial Office,

Frontiers Media SA, Switzerland

${ }^{*}$ Correspondence:

Roberta Russo

roberta.russo@unina.it

†These authors have contributed equally to this work

Specialty section: This article was submitted to Red Blood Cell Physiology,

a section of the journal

Frontiers in Physiology

Received: 10 July 2020

Accepted: 13 July 2020

Published: 11 August 2020

Citation:

Russo R, Marra R, Andolfo I, De Rosa G, Rosato BE, Manna F, Gambale A, Raia M, Unal S, Barella S and Iolascon A (2020) Corrigendum:

Characterization of Two Cases of Congenital Dyserythropoietic Anemia

Type I Shed Light on the Uncharacterized C15orf41 Protein.

Front. Physiol. 11:940.

doi: 10.3389/fphys.2020.00940

\section{Corrigendum: Characterization of Two Cases of Congenital Dyserythropoietic Anemia Type I Shed Light on the Uncharacterized C15orf41 Protein}

\author{
Roberta Russo ${ }^{1,2 *}$, Roberta Marra ${ }^{1,2 \dagger}$, Immacolata Andolfo ${ }^{1,2}$, Gianluca De Rosa ${ }^{1,2}$, \\ Barbara Eleni Rosato ${ }^{1,2}$, Francesco Manna ${ }^{2}$, Antonella Gambale ${ }^{1,2}$, Maddalena Raia ${ }^{2}$, \\ Sule Unal ${ }^{3}$, Susanna Barella ${ }^{4}$ and Achille Iolascon ${ }^{1,2}$ \\ ${ }^{1}$ Dipartimento di Medicina Molecolare e Biotecnologie Mediche, Università degli Studi di Napoli Federico II, Naples, Italy, \\ ${ }^{2}$ CEINGE Biotecnologie Avanzate, Naples, Italy, ${ }^{3}$ Division of Pediatric Hematology, Hacettepe University, Ankara, Turkey, \\ ${ }^{4}$ SSD Talassemie, Anemie Rare e Dismetabolismi del Ferro, Ospedale Pediatrico Microcitemico Antonio Cao, Azienda \\ Ospedaliera Brotzu, Cagliari, Italy
}

Keywords: CDA (I-III), C15ORF41, functional characterization of proteins, genetic testing, anemia

\section{A Corrigendum on}

Characterization of Two Cases of Congenital Dyserythropoietic Anemia Type I Shed Light on the Uncharacterized C15orf41 Protein

by Russo, R., Marra, R., Andolfo, I., De Rosa, G., Rosato, B. E., Manna, F., et al. (2019). Front. Physiol. 10:621. doi: 10.3389/fphys.2019.00621

In the published article, there was an error in affiliation 3. Instead of "SSD Talassemie, Anemie Rare e Dismetabolismi del Ferro, Ospedale Pediatrico Microcitemico Antonio Cao, Azienda Ospedaliera Brotzu, Cagliari, Italy", it should be "Division of Pediatric Hematology, Hacettepe University, Ankara, Turkey".

The authors apologize for this error and state that this does not change the scientific conclusions of the article in any way. The original article has been updated.

Copyright () 2020 Russo, Marra, Andolfo, De Rosa, Rosato, Manna, Gambale, Raia, Unal, Barella and Iolascon. This is an open-access article distributed under the terms of the Creative Commons Attribution License (CC BY). The use, distribution or reproduction in other forums is permitted, provided the original author $(s)$ and the copyright owner(s) are credited and that the original publication in this journal is cited, in accordance with accepted academic practice. No use, distribution or reproduction is permitted which does not comply with these terms. 